\title{
IDENTITAS BUDAYA TORAJA DALAM NOVEL PUYA KE PUYA KARYA FAISAL ODDANG
}

\author{
Tristanti Apriyani \\ Program Studi Sastra Indonesia, Fakultas Sastra, Budaya dan Komunikasi \\ Universitas Ahmad Dahlan, Yogyakarta \\ tristanti.apriyani@idlitera.uad.ac.id
}

DOI:

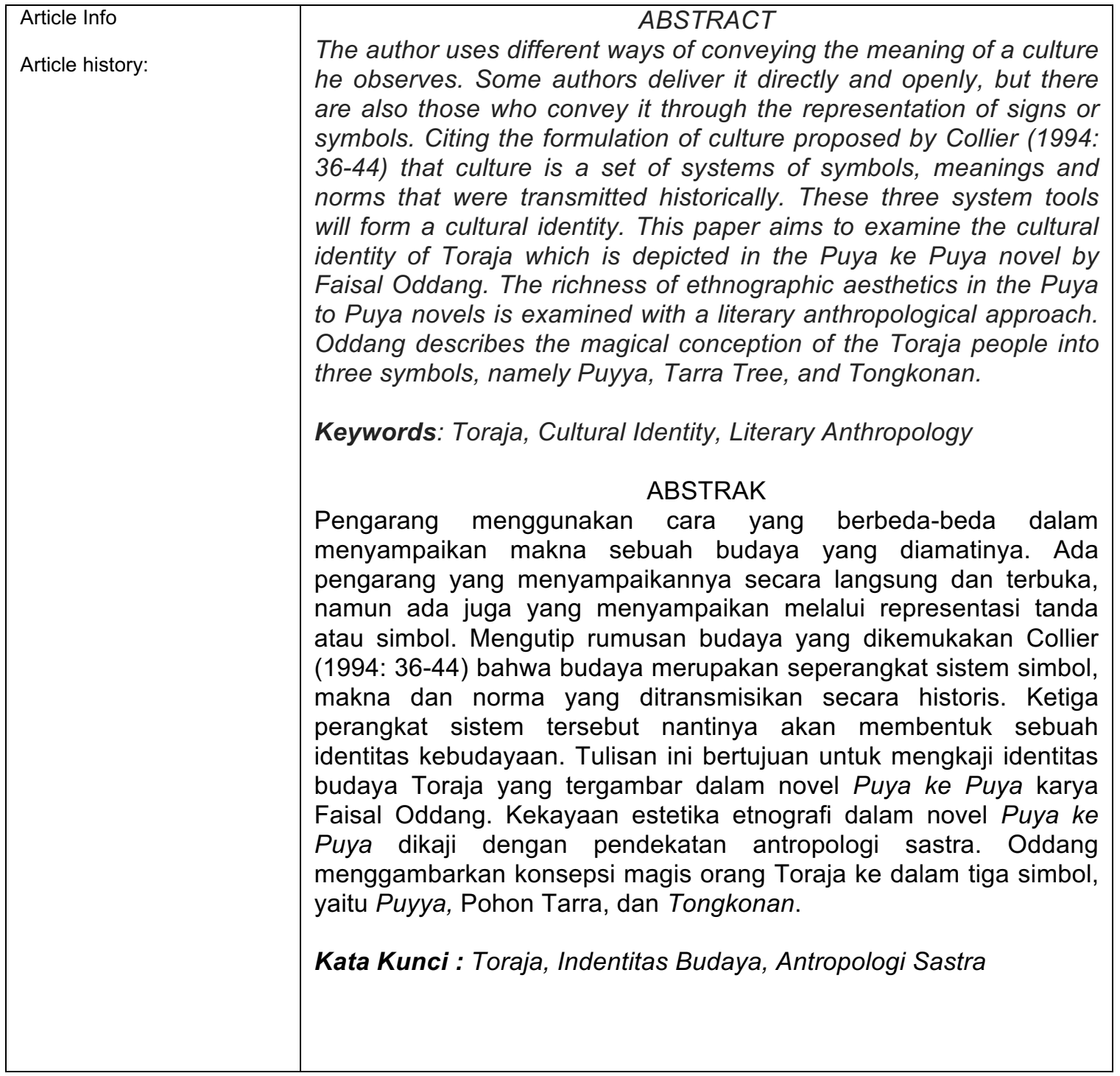




\section{PENDAHULUAN}

Karya sastra merupakan karya seni yang menjadi bagian dari kebudayaan. Menurut Ratna (2010) manusia dalam masyarakat merupakan objek kajian sastra dan kebudayaan. Sementara pemilik suatu kebudayaan itu sendiri adalah masyarakat. Permasalahan yang ditampilkan dalam sebuah karya sastra tidak terlepas dari kebudayaan yang melatarbelakanginya.

Sebagai negara multikultural, Indonesia memiliki tingkat pluralitas sosial yang sangat kompleks dan majemuk. Geertz (1996) menggambarkan Indonesia sebagai sebuah bangsa yang memiliki perjalanan sejarah yang sama dan membentuk struktur ideologis, ekonomis dan politis dengan ukuran makna dan ukuran yang berbeda-beda. Seluruh keanekaragaman tersebut hidup dalam sebuah harmoni untuk membangun sebuah sistem nilai yang menjadi kekayaan dalam masyarakat.

Masyarakat

pendukung

kebudayaan mempunyai harapan untuk melestarikan budaya dan tradisi masingmasing. Demikian pula dengan masyarakat Tana Toraja yang memegang teguh kebudayaan dan kepercayaan leluhur, serta tetap berupaya melestarikan tradisi, seperti upacara perkawinan, upacara kelahiran, upacara kematian dan sebagainya. Hal ini tampak dengan masih digelarnya berbagai upacara adat yang dilakukan masyarakat pendukung kebudayaan Tana Toraja, seperti yang diuraikan dalam novel Puya ke Puya.
Faisal Oddang sebagai pengarang novel Puya ke Puya mengungkapkan realitas budaya Tana Toraja dalam karya sastranya. Di tahun 2014 novel ini memenangkan sayembara novel Dewan Kesenian Jakarta sebagai pemenang keempat dan di tahun 2015 novel ini merupakan novel terbaik versi Tempo. Dengan latar cerita yang sangat kental, novel Puya ke Puya banyak mengulas adat istiadat Toraja yang hingga saat ini masih dilestarikan. Dalam penyajiannya penulis tak jarang menggunakan bahasa atau istilah asli. Hal ini menunjukan bahwa novel ini menyimpan kekayaan kebudayaan yang dapat dikaji secara etnografi.

Salah satu tradisi budaya yang diceritakan dalam novel ini adalah tradisi pemakaman dikenal dengan Rambu Solo. Upacara Rambu Solo dilakukan pada waktu matahari terbenam (Gundara, 2016 : 3). Upacara ini dilandasi oleh kepercayaan dan keyakinan kepada leluhur atau yang disebut dengan Aluk Todolo. Tujuan utama dari upacara ini adalah agar arwah dari yang meninggal diterima dan dapat terus ke Puya (Surga).

Pelaksanaan upacara Rambu Solo ini tidak terbatas dilakukan oleh para pendukung kebudayaan yang tinggal di Toraja saja, namun juga bagi mereka yang tinggal di luar Toraja. Teguhnya pendirian untuk terus melestarikan tradisi upacara Rambu Solo dan pandangan tokoh utama terhadap pelaksanaan tradisi, mitos, mayat, arwah hingga tujuan akhir manusia yaitu Puya digambarkan oleh penulis novel Puya ke Puya secara 
terbuka. Dengan demikian novel ini dapat memberikan gambaran pengetahuan tentang tradisi Tana Toraja yang syarat akan kandungan nilai budaya adi luhung.

Dalam upacara Rambu Solo dikenal konsep Puang Matua sebagai pencipta manusia dan alam dengan segala isinya. Agar kehidupan alam semesta menjadi seimbang dan teratur Puang Matua menetapkan Aluk Todolo sebagai perangkat norma dan aturan yang Pemali. Pemali inilah yang menjadi pedoman hidup masyarakat Tana Toraja dipegang teguh hingga kini.

Faisal Oddang dalam menciptakan novel Puya ke Puya, seolah-olah menciptakan dunia baru yang mungkin saja mirip dengan dunia nyata atau bahkan mungkin berbeda. Hal ini sejalan dengan yang diungkapkan Ratna (2012:15) bahwa karya sastra pada dasarnya membangun dunia yang membentuk citra tentang dunia tertentu, sebagai dunia baru. Kehadiran tokoh utama, Allu yang berasal dari golongan bangsawan Toraja berusaha untuk mendobrak tradisi dan adat-istiadat yang diyakini di Tana Toraja. Meski pada akhirnya Allu pun menyerah dan melaksanakan tradisi tersebut.

Sastra dan kebudayaan memiliki keterkaitan secara dialektik. Kebudayaan yang merupakan hasil aktifitas manusia dijadikan bahan utama dalam menulis karya sastra. Dalam hal ini sastra berfungsi melegitimasi berbagai aspek kebudayaan hasil interaksi manusia. Tanpa adanya aspek kebudayaan tersebut karya sastra tidak akan tercipta (Ratna,
2011:191). Disadari atau tidak sebuah karya sastra juga erat kaitannya dengan latar belakang pengarang. Dalam menciptakan karya sastra seorang pengarang melakukan proses pengamatan terhadap situasi budaya masyarakat sekelilingnya. Seorang pengarang yang memiliki wawasan budaya yang luas akan menyertakan pengetahuan budaya yang diketahuinya itu di dalam proses imajinatif penciptaan karya sastranya.

$$
\text { Untuk menyampaikan makna }
$$
sebuah budaya yang diamatinya, pengarang menggunakan cara yang berbeda-beda. Ada pengarang yang menyampaikannya secara langsung dan terbuka, namun ada juga yang menyampaikan melalui representasi tanda atau simbol. Mengutip rumusan budaya yang dikemukakan Collier (1994: 36-44) bahwa budaya merupakan seperangkat sistem simbol, makna dan norma yang ditransmisikan secara historis. Dalam hal ini budaya terdiri dari tiga komponen utama yang saling berkaitan, yakni simbol dan makna, norma-norma, serta perjalanan sejarah. Ketiga komponen ini nantinya akan membentuk sebuah identitas kebudayaan.

$$
\text { Collier (1994: 43) juga }
$$
merumuskan bahwa identitas budaya tercipta jika suatu kelompok masyarakat menciptakan sebuah sistem sistem simbol budaya yang untuk mengemukakan gagasan mereka tentang layak dan tidaknya sebuah praktik budaya. Selanjutnya sistem simbol tersebut diturunkan kepada anggota kelompoknya. Sementara menurut Ting-Toomey 
(1999:30), identitas budaya merupakan perasaan (emotional significance) dari seseorang untuk ikut memiliki (sense of belonging) atau berafiliasi dengan kultur tertentu. Dapat disimpulkan bahwa identitas budaya merupakan karakteristik khusus yang dimiliki suatu kelompok dalam hal kebiasaan hidup, adat istiadat, bahasa, nilai dan norma.

Pengarang menguraikan gambaran sebuah budaya di dalam karya sastranya memanfaatkan bahasa sebagai medianya. Faruk (2011: 49) menjelaskan bahwa bahasa memiliki peran sebagai indikator dalam sebuah realitas sosial dan mampu memelihara serta mengkonstruksi realitas sosial tersebut. Faruk (2011: 50) pun menyitir pernyataan Berger dan Lukman bahwa bahasa dapat memberikan perubahan dari dunia sosial budaya yang objektif menjadi kesadaran subjektif masyarakat dalam realitas sosial budaya. Demikian pula halnya penggambaran sebuah identitas budaya pengarang memanfaatkan Bahasa di dalam karya sastranya.

Tulisan ini bertujuan untuk mengkaji identitas budaya Toraja yang tergambar dalam novel Puya ke Puya karya Faisal Oddang. Kekayaan estetika etnografi dalam novel Puya ke Puya membuat peneliti merasa tertarik untuk mengkaji karya Faisal Oddang tersebut dengan pendekatan antropologi sastra. Pendekatan yang digunakan dalam mengkaji novel ini dinilai sesuai karena memiliki kemampuan maksimal untuk mengungkapkan berbagai permasalahan kebudayaan. Pendekatan antropologi sastra sebagai salah satu pendekatan interdisipliner memiliki hubungan dengan kajian budaya. Antropologi sastra dapat menampilkan aspek-aspek estetis, hubungan model analisis wacana, serta korelasi antara karya sastra dengan nilainilai kebudayaan pada masa tertentu. Ratna (2011a: 156) bahkan menyitir pernyataan Winner (1988) yang menyebutnya bahwa antropologi sastra sebagai pendekatan etnosemiotik. Ratna (2011a:158) pun berpendapat bahwa antropologi sastra belum sepenuhnya diakui keberadaannya secara metodologis di dalam memahami karya sastra. Diperlukan adanya pengkajian teori-teori yang dapat digunakan dalam penelitian antropologi sastra. Kekayaan estetika etnografi dalam teks tersebutlah yang membuat peneliti merasa tertarik untuk mengkaji karya Faisal Oddang tersebut dengan pendekatan antropologi sastra.

\section{METODE PENELITIAN}

Novel Puya Ke Puya karya Faisal Odang dikaji dengan menggunakan metode penelitian deskriptif kualitatif. Data deskriptif berbentuk diksi tertulis mengenai kondisi, fenomen baik individu maupun kelompok yang diamati (Moleong, 2008). Mengacu pada batasan tersebut maka data deskriptif yang disajikan dalam penelitian ini berupa kumpulan dialog para tokoh yang menggambarkan peristiwa yang memiliki makna atau nilai-nilai kebudayaan. Sementara itu sumber data yang digunakan berupa kutipan dialog antar tokoh, perilaku tokoh dan pemikiran 
pengarang dalam memperlihatkan nilainilai budaya di kehidupan masyarakat.

Teknik pengumpulan data dilakukan dengan teknik studi dokumen dalam bentuk novel, yaitu dengan cara mengumpulkan data berupa arsip-arsip dokumen, termasuk buku-buku dan jurnal-jurnal. Teknis analisis data ini berpedoman pada teknik kajian antropologi sastra yang dipadukan dengan teknik membaca hermeneutika dengan cara memahami dan menafsirkan teks. Palmer (2003: 15-16) menyatakan bahwa terdapat dua fokus kajian dalam hermeneutika, yaitu pemahaman dan interpretasi terhadap teks. Hal ini sepemahanan dengan Ratna (2011: 352) yang menyatakan bahwa fokus kajian hermeneutika adalah kemampuan bahasa sebagai wacana atau teks.

Untuk teknik analisis data, penulis menggunakan analisis deskriptif kualitatif model Miles dan Huberman (2014) dengan cara membaca novel dan memahami isi novel Puya ke Puya. Kemudian penulis mengkaji nilai-nilai budaya yang ditemukan di dalam novel Puya ke Puya dan mendeskripsikan serta menganalisis nilai-nilai budaya tersebut. Langkah terakhir adalah menarik kesimpulan sebagai jawaban atas semua permasalahan dalam penelitian. Sementara itu proses triangulasi data berupa triangulasi teori, triangulasi sumber data dan triangulasi peneliti, dilakukan penulis untuk mengecek keabsahan data.

\section{HASIL \\ PEMBAHASAN}

\section{Upacara Pemakaman Rambu Solo}

Tradisi Rambu Solo adalah upacara kematian budaya Toraja yang merupakan simbol penghormatan terakhir kepada orang yang sudah meninggal. Upacara ini digelar dengan sangat meriah dan mewah. Orang Toraja meyakini bahwa dengan mengadakan upacara Rambu Solo, roh orang yang sudah meninggal dapat menuju tujuan akhir kehidupan yaitu surga (Puya). Pada upacara ini simbol-simbol yang digunakan memiliki peran yang sangat penting, salah satunya adalah digunakannya simbol hewan kerbau sebagai syarat utama dalam upacara kematian Rambu Solo.

Hewan Kerbau dijadikan simbol kendaraan yang akan membawa roh tersebut menuju Puya. Dalam budaya Toraja hewan kerbau memang memiliki nilai yang tinggi dan dianggap sebagai simbol kemakmuran. Sairubang, dkk (2011: 122) menjelaskan bahwa hewan kerbau melambangkan kesejahteraan sekaligus menandakan tingkat kesejahteraan dan status social pemiliknya. Hewan kerbau yang digunakan dalam upacara Rambu Solo adalah hewan kerbau berjenis Tedong Bonga (kerbau belang). Oleh karena dianggap suci, kerbau jenis ini mendapat perlakuan khusus sejak kerbau sejak kecil.

Pelaksanaan upacara Rambu Solo bagi masing-masing golongan masyarakat 
tentunya berbeda-beda. Misalnya jika golongan bangsawan atau golongan Rapasan meninggal dunia maka jumlah kerbau yang dijadikan untuk persembahan dalam upacara Rambu Solo jauh lebih banyak dibandingkan dengan masyarakat biasa. Jumlah kerbau dapat berkisar 24 sampai dengan seratus ekor kerbau. Sementara itu, masyarakat golongan menengah (golongan Tana'bassi), diwajibkan mempersembahkan 8 ekor kerbau ditambah dengan 50 ekor babi, dengan memakan waktu sekitar 3-7 hari. Apabila jumlah kerbau belum mencukupi, maka jenazah tidak boleh disimpan atau dikuburkan di tebing atau tempat tinggi. Oleh sebab itu tidak jarang jenazah disimpan selama bertahun-tahun di atas rumah atau di atas Tongkonan (rumah adat Toraja) sampai akhirnya keluarga almarhum dapat menyiapkan hewan kurban (Embon dan Saputra, 2018 : 4).

Demikian pula yang diyakini masyarakat Kampung Kete' dalam Novel Puya ke Puya. Allu Ralla sebagai seorang mahasiswa jurusan sastra di Makasar, yang mana mendiang ayahnya yang bernama Rante Ralla adalah seorang kepada adat di Kampung Kete', harus mengadakan upacara Rambu Solo dengan mempersembahkan kerbau dan babi dalam jumlah yang banyak. Bagi orang Toraja kematian merupakan proses perjalanan menuju Puya. Mayat diusung ke dalam peti dan diarak menuju tebing tempat peristirahatan terakhir orang Toraja. Tradisi Rambu Solo ini merupakan tradisi turun temurun yang dilakukan masyarakat Toraja.

"Kematian. Kebanyakan orang Toraja merayakan sekarib masa lalu kepada kenangan. Orang-orang bersaput kain hitam berkerumun. Mereka mengantar kerabat yang ingin berjalan ke puya, alam tempat menemui Tuhan. Di dalam peti kayu yang diarak itu, apakah kau lihat tubuh Rante Ralla yang ringkih?"(Oddang, 2015:3).

Kepercayaan bahwa orang yang meninggal dapat langsung menuju Puya dengan tenang jika dilaksanakan upacara Rambu Solo berlaku bagi semua orang Toraja, terutama golongan bangsawan atau orang terpandang. Penundaan pelaksanaan upacara Rambu Solo akan menyebabkan arwah seseorang tetap berkeliaran seperti layaknya manusia yang masih hidup, tampak pada kutipan di bawah ini :

"dulu kampung ini hanya akan ramai jika ada kematian yang dirayakan. Ketika ada mayat "sakit" yang diarak. Iya, sakit. Kau mengerti juga, bukan? Bagi orang Toraja, sebelum Rambu Solo, semua mayat masih sakit. Selayaknya mereka yang sakit, kerabat tetap mengajaknya berbicara. Memberi mereka makan, rokok, serta sirih. Kini di sekitar rumah Rante Ralla, kampung kete' kau akan temukan keramaian hampir setiap hari. (Oddang, 2015: 13).

Upacara Rambu Solo diawali dengan prosesi ma'pasulluk yaitu 
pertemuan keluarga yang tujuannya menyepakati kesanggupannya untuk menyediakan hewan kurban berupa kerbau (Embon dan Saputra, 2018: 7).

"Aku takjub bukan main ketika kubuka daun pintu dan kudapati puluhan kerbau dan ratusan babi di depanku. Aku tahu kerbau dan babi itu adalah kerbau yang pernah dipersembahkan saat aku dirambu Solo”. (Oddang, 2015 : 183)

Hal ini memicu adanya konflik dalam diri Allu Ralla yang tinggal jauh dari Tana Toraja. Ia menolak untuk melaksanakan uparaca Rambu Solo yang menghabiskan biaya yang sangat besar. Sementara kerabatnya memaksa Allu Ralla untuk segera mempersiapkan dan melaksanakan upacara Rambu Solo karena tidak ingin menanggung malu yang berkepanjangan. Akan tetapi Allu Ralla cenderung menyarankan agar mendiang ayahnya yang telah meninggal 17 tahun lalu dimakamkan di Makasar saja.

"saya ingin menguburkan Ambe di Makkasar," kata saya kepada kerabat yang membentuk lingkaran kecil di tengah Tongkonan yang mulai lengang", (Oddang, 2015: 10)

"ibu pohon mengatakan, apalagi sebagai penuluan tertua, pimpinan Tongkonan di Kete-Ambe harus bikin mewah acaranya" (Oddang, 2015:12).

"Kau paham. Jika tak ada Rambu Solo, wajah kerabat akan tercoreng. Gengsi keluarga Ralla akan jatuh mirip buah ranum yang menimpa bebatuan. Akan remuk harga diri mereka." (Oddang, 2015:33)

Dalam novel Puya ke Puya dipaparkan ritual ma'popengkalao yaitu penurunan mayat ke lumbung untuk disemayamkan. Lumbung tersebut memang khusus digunakan untuk tempat menyimpan mayar. Lumbung terletak di bagian depan tongkongan induk. Oddang menggambarkannya seperti kutipan di bawah ini :

"hari ini mayatku akan diturunkan ke lumbung di bagian depan Tongkonan induk. Yang memang kerap digunakan menyimpan jenazah menjelang keberangkatan ke puya. Orang-orang menyebut acara ini sebagai ma'popengkaloa. Jenazahku disemayamkan tiga hari tiga malam di dalam lumbung sebelum diadakan upacara ma'pasonglo dan menaikkan jenazahku ke keranda jenazah yang telah dihiasi macam-macam ukiran dan berbentuk miniatur Tongkonan-saringan namanya" (Oddang, 2015: 137).

Sebagai orang Toraja yang telah mengenyam pendidikan dan tinggal di luar wilayah budaya Toraja, memahami tradisi Toraja terutama Rambu Solo, sebagai sebuah tradisi yang tidak relevan dengan perkembangan zaman saat ini. Allu Ralla tidak merasa perlu untuk mempertahankan tradisi tersebut, seperti yang termuat pada kutipan berikut :

"Kebudayaan adalah produk manusia, manusia dan kebudayaan itu dinamis sesuai ruang dan waktu, dan relevansi 
dengan zaman sangat penting sebagai acuan untuk mempertahankan sebuah tradisi yang merupakan bagian dari kebudayaan. Acuan untuk tetap melakukannya atau tidak, dan saya pikir zaman sudah tidak relevan dengan yang kalian pertahankan" (Oddang, 2015:20).

\section{Konsep Alam Gaib Orang Toraja}

$\begin{array}{crr}\text { Magis } & \text { merupakan } & \text { keadaan } \\ \text { alam/lingkungan } & \text { kehidupan } & \text { yang }\end{array}$ keberadaannya bersifat irrasional, yang memiliki tidak terlihat, tersembunyi atau bahkan tidak nyata. Kepercayaan yang dianut orang Toraja disebut dengan Aluk Todolo. Menurut Aluk Todolo, kematian adalah suatu proses hidup manusia di dunia dan merupakan bayangan hidup kemudian. Artinya segala yang dilakukan di dunia nyata maka akan dialami di alam gaib.

Novel Puya ke Puya menggambarkan Aluk Todolo sebagai kepercayaan orang Toraja. Aluk Todolo mengasumsikan sebuah dunia dipenuhi dengan karakter-karakter magis yang memiliki perasaan seperti halnya yang dialami oleh manusia biasa. Mereka meyakini bahwa dunia dijaga oleh para leluhur yang memiliki kekuatan gaib. Oddang menggambarkan konsepsi magis orang Toraja ke dalam tiga simbol, yaitu pohon Puyya, Pohon Tarra dan Tongkonan.

\section{a. Puya}

Menurut kepercayaan Aluk Todolo, kehidupan dan kematian merupakan keberlanjutan kehidupan dari alam fana ke alam arwah atau yang disebut dengan Puya. Kehidupan dan kematian tidak memiliki batas yang jelas.
Kematian hanyalah merupakan perubahan bentuk, alam dan wujud. Kehidupan merupakan jembatan emas untuk sampai ke alam gaib, dimana arwah tetap dapat mengadakan hubungan dengan kehidupan manusia di alam nyata.

Sementara itu, semua yang dilakukan di alam fana merupakan refleksi kehidupan di puya. Konsepsi ini disimbolkan dengan beberapa bentuk pengorbanan di setiap tahapan upacara kematian, misalnya berupa penyediaan bekal kubur. Kesempurnaan tahapan dalam upacara kematian seseorang dan status sosialnya ketika hidup, akan menentukan dimana posisi arwahnya itu berada. Seperti tertera pada kutipan di bawah ini :

Di puya, leluhur sedang bingung. Bagaimana cara mengatasi masalah yang timbul di bumi? Atau paling tidak mengatasi masalah di kampung Kete’. Itu yang paling utama. Leluhur harus bertanggung jawab atas anak cucu mereka. (Oddang, 2015: 208)

Puya merupakan tempat peristirahatan yang abadi. Tempat ini merupakan tempat berkumpulnya arwah para leluhur. Wujud arwah manusia ditentukan oleh kesempurnaan ritual pada upacara Rambu Solo. Belum pastinya nasib wujud arwah ini tergambar pada kutipan berikut :

"Soal rohku yang kini masih tergatung antara langit dan bumi, menjadi bambo karena belum diupacarakan, biarlah menjai tanggunganku sendiri, biarlah kuderitakan sendiri" (Oddang, 2015:32).

Bambo yang dimaksud pada kutipan di atas adalah arwah yang 
gentayangan karena keluarga yang ditinggalkan belum melaksanakan upacara Rambu Solo. Dalam hal ini nasib arwah menjadi belum jelas keberadaannya. Kutipan tersebut juga membuktikan bahwa keberadaan Aluk (Tuhan) sangat diyakini dan dijunjung tinggi oleh orang Toraja.

\section{b. Pohon Tarra}

Keberadaan Pohon Tarra sudah ada sejak ratusan tahun lalu, sama usianya dengan adat Passiliran sudah dilakukan oleh nenek moyang orang Toraja yang menganut kepercayaan Aluk Todolo. Pohon Tarra hanya dapat tumbuh dan ditemukan di bisa ditemukan di Desa Kambira, Tana Toraja, Sulawesi Selatan (KSPN Toraja, 2016). Pohon ini dapat tumbuh dengan ukuran yang sangat besar mencapai diameter sekitar 80 hingga 100 $\mathrm{cm}$. Oddang menggambarkannya seperti kutipan di bawah ini :

"Tujuh belas tahun yang lalu, keluarga Ralla juga berduka. Mereka kehilangan Maria Ralla, balita lima bulan yang meninggal tiba-tiba. Maria semalaman menangis tidak berhenti. Penyebabnya jelasnya tidak ada yang tahu. Ambenya, Rante Ralla, mengatakan bahwa anak mereka menderita sakit paru. Ya, sakit perut yang tidak biasa. Sejak saat itu tubuh Maria Ralla dikubur di pohon tarra. Pohon bersar bergetah sewarna air susu. Dipercayai sebagai pengganti ibu. Orang Toraja menyebutnya makam passiliran” ( Oddang, 2015:11).

"Sudah lama aku mau pulang ke rumah tempat orang tuaku. Sejak tujuh belas tahun yang llau, aku dirawat oleh ibu yang baru, sebelum akhirnya menuju puya- menuju surga. Begitu kata ibu yang baru. Ibu pohon, katanya lagi, aku tinggal menunggu tubuhku dihancurkan batang pohon, menyatu bersama getahnya yang kami susui, menyatu dengan rantin, menjadi daun, lalu kering, lalu jatuh kembali ke tanah, kembali ke asal dan kembali kesurga" (Oddang 2015: 11).

Oddang menggambarkan bahwa mayat bayi yang belum cukup umur (usia dibawah 6 bulan) di kuburkan ke dalam pohon Tarra yang dianggap sebagai pengganti ibu mereka. Maria sang bayi itu akan hidup di pasiliran selama kurang lebih 17 tahun sebelum mereka pergi ke Puya. Selama itu pula Maria akan menunggu ayahnya untuk pergi ke Puya bersama-sama. Memang pohon Tarra merupakan salah satu pohon yang memiliki banyak getah berwarna putih. Getah berwarna putih ini dipercaya dapat menjadi pengganti ASI (Air Susu Ibu). Pohon ini merupakan tempat peristirahatan terakhir untuk bayi-bayi yang meninggal dunia.

"Maria anakku, kau di dalam rahim ibu yang lain sekarang. Baik-baik di sana. Sebab di sini, kerabatmu tak hentinya mengirimkan doa buatmu, Nak, O iya, Maria bagaimana dengan ibu barumu? Dia pasti pohon perawat sekaligus sebagai ibu yangh baik bagi anak-anak yang lain. Di dalam peti mati ini tubuhku tak henti-hentinya mengharapkan segera bertemu denganmu. Bagaimana rupamu sekarang? Pasti kamu cantik. Apakah mewarisi bola mata indomu? Yang cerlang itu? Semoga saja Maria”. (Oddang, 2015 : 129). 
Mayat bayi yang dapat disimpan atau dimakamkan di pohon Tarra ini adalah mayat bayi yang usianya belum berusia 6 bulan dan belum tumbuh gigi. Mayat bayi disimpan dan dimasukkan ke dalam pohon Tarra yang dilubangi sesuai dengan ukuran badan sang bayi. seperti kutipan yang tertera di bawah ini :

Maria Ralla yang paling disukai. Iya, disukai. Oleh mayat lelaki tentunya. Ada banak mayat di pohon itu. Laki- laki perempuan bercampur. Banyak mayatmayat lelaki. Secara jasad masih bayi. Giginya tak tumbuh. Tapi arwahnya telah remaja. Bahkan dewasa. Hanya saja, dewasa dalam pohon, beda dengan dewasa di dunia. Alam yang berbeda. (Oddang, 2015: 43)

Meski dalam satu pohon ditempati banyak mayat bayi, namun pohon ini tidak pernah mengeluarkan bau busuk. Hal ini didasari keyakinan bahwa pohon Tarra adalah wujud yang menghidupi. Mayat bayi yang dimasukkan ke dalam pohon Tarra dengan sendirinya akan menyatu berkat adanya getah pohon Tarra yang berwarna putih. Pada kenyataannya setelah 20 tahun, pohon Tara akan kembali dalam keadaan bersih dan dapat ditempati mayat bayi lainnya.

Pagi ini aku minum susu lebih banyak dari getah tubuh Ibu Pohon. Aku juga sempat mengambil sebagian dari susu milik Bumi Tandiongan. Kata Ibu Pohon, Bumu setahun lebih muda dariku. Ia baru enam belas tahun di makam passiliran ini. (Oddang, 2015: 13)

Mengacu pada kutipan pohon besar yang dinamakan Pohon Tarra atau makam passiliran merupakan kehidupan lain. Seperti yang di rasakan Maria dan Bumi sejak mereka masih bayi. Pohon Tarra diasumsikan ibu mereka yang menjaga dan memberi makan mereka selama di makam passiliran.

\section{c. Tongkonan}

Tongkonan merupakan rumah adat Toraja yang penuh makna. Latar belakang arsitektur rumah tradisional Toraja didasari falsafah budaya Toraja. Bentuk Tongkonan setiap daerah memiliki ciri khas masing-masing. Namun demikian, secara kasat mata bentuknya hampir sama. Perbedaan ciri khas tersebut memberikan kekayaan rupa dan bentuk Tongkonan (Sultan, dkk, 2014: 41).

Tongkonan berasal dari kata "tongkon" yang artinnya duduk. Bangunan Tongkonan selalu dibangun menghadap ke utara (ulunna lino). Hal ini merupakan simbol penghormatan pada Puang Matua. Bagian selatan Tongkonan (pollo'na lino) menghadap ke arah pollo' banua atau puya. Bagian ini merupakan representasi hubungan antara para leluhur dan kehidupan setelah kematian. Bagian timur (matallo) merupakan simbol hubungan dengan para dewa, sedangkan bagian barat (matampu') merupakan simbol hubungan para leluhur yang dihormati (Indratno, dkk, 2016: 78).

Tongkonan merupakan sebuah hunian yang memiliki fungsi, tugas, dan kewajiban. Tongkonan pun dapat diartikan sebagai suatu sistem kekerabatan yang didasarkan pada prinsip sang rara sang buku (sedarah dan setulang). Dengan kata lain Tongkonan merupakan simbol keberadaan keluarga 
dan sebagai simbol pusat berkumpulnya kekerabatan atau rumpun keluarga. Seperti kutipan dibawah ini :

"Semua kerabat yang memiliki pertalian dengan keluarga Ralla akan dating ke Tongkonan, mereka tentu akan menyumbangkan pemikiran tentang bagaimana seharusnya kami memperlakukan mayat Ambe." (Oddang, 2015 :16).

Tongkonan merupakan tempat bermusyawarah untuk mentukan segala hal yang harus diputuskan oleh keluarga. Jika mufakat belum tercapai maka seluruh anggota keluarga akan menjadwalkan kembali rapat di Tongkonan yang sama hingga tercapainya kesepakatan. (Hidayah, 2018: 6). Selain sebagai tempat tinggal dan rumah adat, Tongkonan berfungsi sebagai tempat penyelenggaraan upacara adat dan upacara keagamaan (Sarungallo dalam Said, 2004: XV). Di depan Tongkonan induk terdapat lumbung yang berfungsi sebagai tempat penyimpanan mayat pada upacara Rambu Solo. Seperti tertera dalam kutipan di bawah ini :

"Hari ini mayatku akan diturunkan ke lumbung di bagian depan Tongkonan induk. Yang memang kerap digunakan menyimpan jenazah menjelang keberangkatan ke puya. Orang-orang menyebut acara ini sebagai ma'popengkaloa. Jenazahku disemayamkan tiga hari tga malan di dalam lumbung sebelum diadakan upacara ma'pasonglo dan menaikkan jenazahku ke keranda jezanah yang telah dihiasi macam-macam ukiran dan berbentuk miniatur Tongkonan-saringan namanya"(Oddang, 2015 : 137).
Ada beberapa larangan berkenaan fungsi Tongkonan sebagai tempat upacara adat dan upacara keagamaan. Jika dalam satu waktu sebuah keluarga harus melaksanakan upacara Rambu Solo dan upacara pernikahan, maka yang harus digelar terlebih dahulu di Tongkongan adalah upacara Rambu Solo. Seperti yang tertera pada kutipan berikut :

"soal pernikahan, Allu. Soal pernikahan dan soal pemakaman, sungguh kau seharusnya sudah mengerti. Di dalam sebuah tongkongan, tidak baik digelar rambu tuka-upacara kenangan macam pernikahan sebelum digelarkan Rambu Solo sebagai upacara kesedihan." (Oddang, 2015 :99)

Seperti telah dikemukakan di atas, bentuk bangunan Tongkonan berusaha mengkomunikasikan segala bentuk falsafah hidup budaya Toraja berdasarkan pandangan Aluk Todolo. Salah satunya adalah pengharapan agar orang Toraja dapat menyesuaikan diri dengan keadaan atau situasi apa pun yang ada dalam kehidupan.

Aku yakin Tina tidak mendengarnya. Kini, ia tengah bersimpih di dekat mayatku. Rapat yan membahas pemakamanku baru saja bubar. Kulihat lelehan air di pipinya. Lukanya dalam, namun ia sekuat pasak-pasak Tongkonan. Perlahan bibirnya bergetar, bergumam, bergumam, kemudian bersuara (Oddang, 2015: 25)

Kutipan di atas menunjukkan bahwa Tongkonan merupakan sebuah bangunan yang kokoh dengan pasakpasak yang menyangganya. Sebagai 
rumah panggung, Tongkonan seakan memiliki kaki-kaki, yang ketinggiannya hampir dua meter dari tanah. Jadi untuk masuk ke rumah, harus menggunakan tangga (Sultan, dkk, 2014: 43). Orang Toraja diharapkan dapat memiliki pendirian sekokoh Tongkonan. Meski dalam kondisi terpuruk sekalipun, orang Toraja harus mampu bertahan dari keterpurukannya.

\section{KESIMPULAN}

Berdasarkan pemaparan kajian di atas, identitas budaya toraja yang digambarkan Faisal Oddang dalam novel Puya ke Puya nampak pada uraian tentang ritual keagamaan orang Toraja, yakni upacara Rambu Solo dan konsep alam gaib Toraja. Ritual keagamaan Rambu Solo diasumsikan sebagai "pintu gerbang" bagi jenazah untuk memasuki alam yang baru. Selain itu bagi masyarakat Toraja, Rambu Solo merupakan salah satu bentuk bakti seorang anak kepada orang tua dan pengikat tali silaturahmi dalam keluarga besar.

Aluk Todolo sebagai kepercayaan orang Toraja dalam novel Puya ke Puta diasumsikan sebagai sebuah dunia yang dipenuhi dengan karakter-karakter magis. Karakter magis tersebut memiliki perasaan seperti halnya yang dialami oleh manusia biasa. Mereka meyakini bahwa dunia dijaga oleh para leluhur yang memiliki kekuatan gaib. Oddang menggambarkan konsepsi magis orang Toraja yang dijadikan sebagai identitas budaya orang Toraja ke dalam tiga simbol, yaitu Puya, Pohon Tara, dan Tongkonan. Puya merupakan tempat peristirahatan yang abadi, merupakan tempat berkumpulnya arwah para leluhur. Kematian menurut kepercayaan Aluk Todolo adalah hanyalah sebuah proses perubahan status dari manusia di dunia menjadi roh manusia di alam gaib. Kehidupan di dunia merupakan jembatan emas menuju alam gaib, di mana arwah tetap dapat mengadakan hubungan dengan kehidupan manusia di alam nyata. Tongkonan merupakan simbol kesatuan relasi antara manusia dan leluhurnya. Tongkonan diibaratkan sebagai pusat kehidupan sosial dan spiritual Suku Toraja, dimana seluruh anggota keluarga diharuskan untuk ikut serta dalam setiap bentuk ritual.

\section{DAFTAR PUSTAKA}

Collier, Mary Jane, 1994, “Cultural Identity and Intercultural Communication", dalam Samovar, Larry A. dan Porter, Ricard E. (eds), Intercultural Communication: A Reader, Berlmont: Wadsworth, h. 36-44.

Embon, Debyani dan Saputra, I Gusti Ketut Alit. 2018. "Sistem simbol dalam upacara adat Toraja rambu solo: kajian semiotik" dalam Jurnal Bahasa dan Sastra Volume 3 No 7 (2018).

Faruk. 2012. Metode Penelitian sastra, sebuah penjelajahan awal. Yogyakarta: Pustaka Pelajar. 
Guntara, Fuad. 2016. "Kajian Sosial Budaya Rambu Solo dalam Pembentukan Karakter Peserta Didik", Jurnal Pendidikan Vol 1, No 2,

Hidayah, Nurul Mei. 2018. "Tradisi Pemakaman Rambu Solo Di Tana Toraja Dalam Novel Puya Ke Puya Karya Faisal Oddang (Kajian Interpretatif Simbolik Clifford Geertz)", Jurnal Interpretatif Simbolok Clifford Geertz, Vol 01, No 01 Tahun 2018.

Indratno, Imam, dkk. 2016. "Silau'na Tongkonan sebagai sebuag realitas Tondok", dalam Jurnal Ethos (Jurnal Penelitian dan Pengabdian Masyarakat) Vol 4, No.1, Januari 2016.

KSPN Toraja. 2016. Rencana pembangunan infrastruktur terpadu kawasan strategis pariwisata pegunungan dan budaya. Jakarta : Pusat Pengembangan Kawasan Strategis Badan Pengembangan Infrastuktur Wilayah Kementrian Pekerjaan Umum dan Perumahan Rakyat.

Miles, M.B, Huberman, A.M, dan Saldana, J. 2014. Qualitative data analysis, a methods sourcebook, edition 3. USA: Sage Publications. Terjemahan Tjetjep Rohindi Rohidi, UIPress.

Moleong, Lexy. 2008. Metodologi Penelitian Kualitatif. Bandung: Remaja Rosdakarya.
Nasir, M. 1992. Metodologi Penelitian. Jakarta: Usaha Nasional.

Oddang, Faisal. 2015. Puya ke Puya. Jakarta: KPG (Kepustakaan Populer Gramedia).

Palmer, Richard E. 2003. Hermeneutika, Teori Baru Mengenai Interpretasi, terj. Musnur Hery. Yogyakarta: Pustaka Pelajar.

Ratna, I Nyoman Kutha. 2011. "antropologi sastra: perkenalan awal (anthropology Literature: an Early Introduction)" dalam Metasastra, Vol. 4 No. 2, Desember 2011.

Ratna, Nyoman Kutha. 2011. Antropologi Sastra Peranan Unsur-unsur Kebudayaan dalam Prosa Kreatif. Yogyakarta: Pustaka Belajar.

Sariubang, Matheus, Qomariyah, R, dan Kristanto, L. 2010. "Peranan ternak kerbau dalam masyarakat adat Toraja di Sulawesi Selatan (The Role of Buffalo in Culture Toraja Ethnic in South Sulawesi)" dalam Prosiding Seminar Nasional Teknologi Peternakan dan Veteriner 2010.

Sultan, St. Hadidjah dan Mayasari, Karina. 2014. "Teknologi dan konstruksi rumah tradisional toraja (Tongkonan) technology and construction of Toraja traditional house (Tongkonan)", dalam Jurnal Masalah Bangunan, Vol. 49 No. 1 Juli 2014. 
Ting-Toomey, Stella. (1999). Communication Across Culture. New York: The Guilford puya karya Faisal Oddang" Publications, Inc.

Wahyuni, Irni. 2018. "Nilai budaya yang terkandung dalam novel puya ke dalam Prosiding Senasbasa, Edisi 2 Tahun 2018. 